\section{Qualitative and quantitative assesment of initial bacterial plaque formation on different prosthetic restorative materials}

\section{Farklı protetik restorasyon materyalleri üzerinde başlangıç bakteriyel plak oluşumunun nitel ve nicel olarak değerlendirilmesi}

Prof. Dr. Ali Murat Kökat

Okan University, Faculty of Dentistry, Department of Prosthodontics, İstanbul Orcid ID: 0000-0002-3752-4858

Prof. Dr. Nesrin Anıl

Hacettepe University, Faculty of Dentistry, Department of Prosthodontics, Ankara Orcid ID: 000-0003-1708-7029

Received: 8 October 2017

Accepted: 17 January 2018

doi: $10.5505 /$ yeditepe.2019.41275

\section{Corresponding author:}

Prof. Dr. Ali Murat Kökat

Aydıntepe Mahallesi, 34947 Tuzla/İstanbul Phone: 4449863

E-mail: alimuratti@gmail.com

\section{SUMMARY}

Aim: The aim of this study was to determine the structure of bacterial plaque qualitatively and quantitatively and to evaluate the effect of restorative material variation on pellicle composition and bacterial adhesion.

Materials and Method: Titanium, Au-Ag-Pd alloy, Ni-Cr alloy, an all-ceramic system and a feldspathic porcelain system were used to evaluate bacterial adhesion and plaque composition characteristics. Acquired pellicle was analyzed by using sodium dodecyl sulphate polyacrylamide gel electrophoresis (SDS-PAGE). Single colony isolated groups on samples were identified by using BBL-Crystal System. Statistical analysis was performed by using Kruskal Wallis Analysis of Variance (ANOVA).

Results: Acquired pellicle analysis by SDS-PAGE revealed amylase content for each group except feldspathic porcelain.Significant qualitative and quantitative differences were found among the materials for bacterial plaque content. Microorganism types varied most for feldspathic porcelain surface. The least variety of microorganisms were found on Cr-Ni. The lowest adhesion was observed on feldspathic porcelain. Conclusion: Initial bacterial plaque shows material specific differences for compositional structure. Bacterial adhesion for each material shows internal compositional variations. Streptococci were found to be most revealed species for all materials studied.

Keywords: Bacterial colonization, prosthetic materials, SDS-PAGE, adsorption, dental plaque

\section{ÖZET}

Amaç: Bu çalışmanın amacı bakteriyel plak yapısını nitel ve nicel olarak değerlendirmek ve restoratif materyal çeşitliliğinin pelikıl kompozisyonu ve bakteriyel adezyon üzerine etkisini incelemektir.

Gereç ve Yöntem: Titanyum, Au-Ag-Pt alaşımı, Ni-Cr alaşımı, feldspatik porselen ve bir tam seramik sistemi kullanılarak materyaller arası farklııklar incelenmiştir. Bu amaçla dairesel olarak hazırlanmış örnekler oral kavitede 2 ve 48 saatlik sürelerle tutulmuştur 2 saat bekletilmiş örnekler üzerindeki kazanılmış pelikıl SDS-PAGE yöntemi ile incelenmiştir. Bakteriyel plak analizi öncesi her bir örnek grubu steril edilmiştir. Örnekleri taşıyan alt tam protez 48 saat süreyle ağız içerisinde tutulduktan sonra örnekler $5 \mathrm{ml}$ steril serum fizyolojik solüsyonu içeren tüplere yerleştirilmiş ve kültür elde edilmiştir. Görsel sayım ve mikroskopik ayrıştırma sonrası izole edilmiş olan tek koloni grupları BBL-Crystal sistemi ile tanımlanmıştır. İstatistiksel değerlendirme için Kruskal Wallis Varyans Analizi uygulanmıştır. Bulgular: SDS-PAGE analizi feldspatik porselen hariç her grupta amilaz içeriği tespit etmiştir. Bakteriyel plak içeriği açısından materyaller arasında istatistiksel olarak belirgin farklılıklar görülmüştür. Mikroorganizma tipleri en büyük çeşitliliği feldspatik porselen üzerinde sergilemiştir. En az çeșitlilik ise Cr-Ni grubunda görülmüştür. En düşük miktarda adezyon da 
feldspatik porselen üzerinde izlenmiştir.

Sonuç: Başlangıç bakteriyel plak içeriği materyale özgü farklılıklar sergilemektedir. Her bir materyal için bakteriyel adezyon yapısal çeşitilikler göstermektedir. Tüm materyal gruplarında en çok görülen tür streptokoklardır.

Anahtar kelimeler: Bakteriyel kolonizasyon, protetik materyaller, SDS-PAGE, adzorpsiyon, dental plak

\section{INTRODUCTION}

Bacterial dental plaque is a deposit of microorganisms embedded in an organic intercellular matrix, ${ }^{1}$ and the major etiologic factor in dental caries and periodontal diseases. ${ }^{2}$ Many studies showed plaque carrying subgingival restorations happen to cause severe inflammation and loss of attachment. ${ }^{3-5}$

Plaque development begins with the adsorption of salivary glycoproteins onto tooth surfaces. ${ }^{6}$ This newly formed layer is called "acquired pellicle". Acquired pellicle formation presents the initial stage of plaque formation on exposed teeth and material surfaces. It consists of salivary proteins and acellular bacterial enzymes and acts as a medium for bacterial adherence. ${ }^{7}$ Microorganism adherence begins immediately after pellicle coating. ${ }^{8,9}$ It has been shown that composition of the plaque on natural teeth and restorations do not differ principally. ${ }^{10-12}$

Adsorption of acquired pellicle depends on saliva composition and surface properties of adsorbant material. Salivary glycoproteins adsorb to chemically different surfaces selectively and microorganisms bind to spesific proteins similarly. ${ }^{6,9}$ So various proteins can dictate which bacteria adhere first and which species develop the plaque. It was shown that qualitative and quantitative variations in acquired pellicle do affect plaque composition and its final pathogenesis. ${ }^{13-15}$ Bacterial plaque amount and composition demonstrates differences related to the restorative material. ${ }^{11,16-18}$

The aim of this study was to determine the structure of bacterial plaque qualitatively and quantitatively and to evaluate the effect of restorative material type on pellicle composition and bacterial adhesion.

\section{MATERIALS AND METHOD}

\section{Materials}

Titanium (Goodfellow Cambridge Limited, Huntington, England), Au-Ag-Pd alloy (Argenco 58; Argen CO., San Diego, California, USA), Ni-Cr alloy (Remanium G soft;Dentaurum, Pforzheim, Deutschland), an all-ceramic system (IPS Empress 2; Williams/ Ivoclar, Amherst, NY, USA) and a feldspathic porcelain system ( Ceramco; Ceramco INC, Burlington, NJ, USA) were used to evaluate bacterial adhesion and plaque composition of various dental restorative materials.
Ten samples of each material were made in disc form $5 \mathrm{~mm}$ in diameter and $1 \mathrm{~mm}$ thick. Titanium discs were obtained from manufacturer in same dimensions. Ceramic samples were produced at the same size according to the manufacturer's recommendations. IPS Empress, $\mathrm{Ni}$-Cr and gold alloy samples were made by casting of disc shaped wax patterns. All samples were ground with 400-4000 grit silicone carbide papers (Microcut, Buehler, USA). Feldspathic porcelain and IPS Empress samples were glazed.

\section{In-vivo pellicle formation and analysis}

Acquired pellicle and bacterial plaque were formed in vivo for this study. An acrylic base plate with five round holes was prepared to be seated on mandibular arch of 34 years old, healthy, edentulous, male volunteer. Samples were placed on the trial denture to be contaminated on both sides (Figure 1).

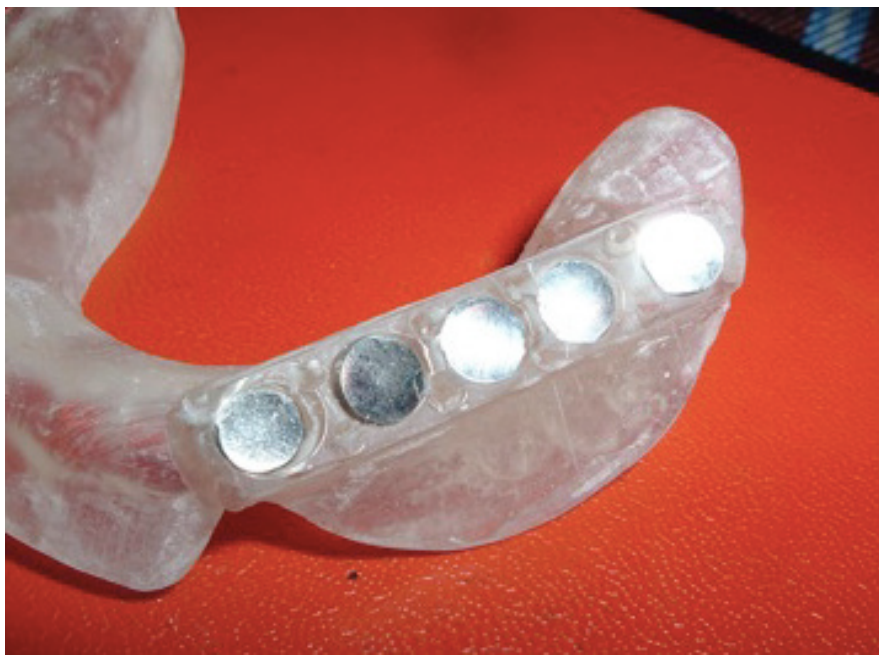

Fig. 1. Samples were placed on the trial denture to be contaminated on both sides

Pellicle formation was achieved after $2 \mathrm{~h}$ insertion period during when no food or drinks were allowed. Five discs per one group were held in the mouth for one session and this procedure was repeated for each group. After 2 $\mathrm{h}$ discs were removed gently and placed in eppendorf tubes containing $2 \mathrm{ml}$ of distilled water and afterwards discs were washed with double distilled water to eliminate non-adsorbed proteins. Discs were then stored in $0.2 \mathrm{M}$ EDTA containing $0.05 \mathrm{M}$ ammonium bicarbonate solution for 48 hours at $4^{\circ} \mathrm{C}$ to set all adsorbed proteins free efficiently. Supernatant were then dialysed against double-distilled water for 24 hours and aqueous samples liophilised at $-70^{\circ} \mathrm{C}$ for another 24 hours before suspending in $1 \mathrm{ml}$. PO4 buffered saline solution.

3. Sodium Dodecyl Sulphate Polyacrylamide Gel Electrophoresis (SDS-PAGE)

Samples were then evaluated by SDS-PAGE for determination of protein and/or amylase contents. $7.5 \%$ seperating gel and $4 \%$ loading gel were used. Loading volume for samples was $10 \mu \mathrm{l}$. Samples were diluated 1:1 with loading buffer prior applying to gel. Samples were denatura- 
ted at $95^{\circ} \mathrm{C}$ for 5 minutes. Then applied to the grooves of gel by Hamilton tube. The samples were run at $120 \mathrm{~V}$ for 1 $\mathrm{h}$ until they passed the stacking gel. As bromphenol blue transversed the gel, process paused and gel inserted to appropriate solution for staining.

Protein bands formed after staining of the gel were compared with the standard's protein bands and were thoroughly examined. Bradford method was used to determine the bands with high protein content. Bovine serum albumine was used as standard.

\section{In vivo bacterial plaque colonization and analysis}

Ten samples were attached to the right and left buccal flanges of lower denture by using self-cured acrylic resin (Figure 2).

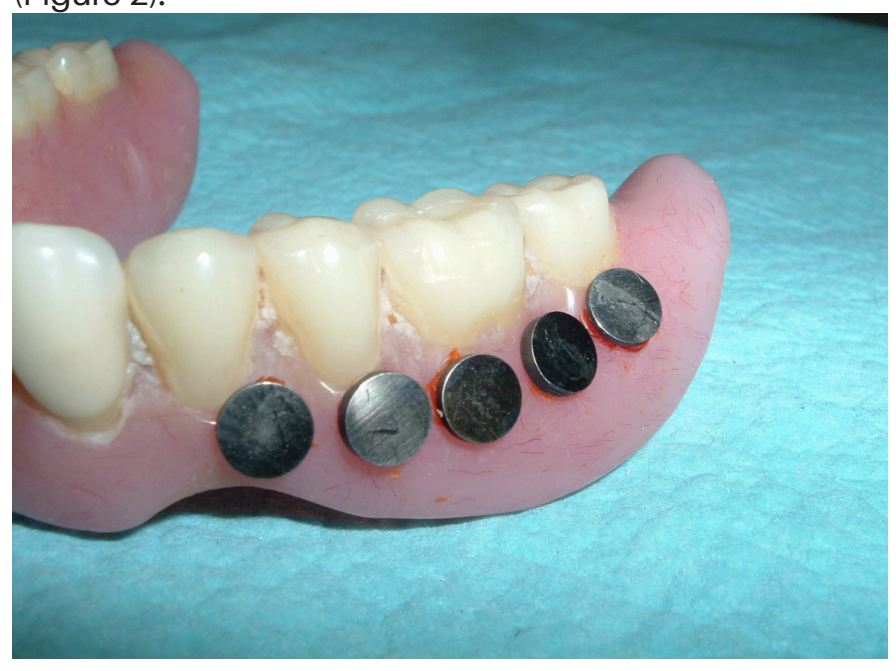

Fig. 2. Samples were attached to the right and left buccal flanges of lower denture by using self-cured acrylic resin.

Prior to the procedure each of the sample group were sterilized. Sample bearing denture was hold in the mouth for 48 hours. During this period the patient was told not to remove his denture, use any medication or perform any cleaning procedure.

Samples were gently removed after 48 hours by using a sterile curette and immediately placed into $5 \mathrm{ml}$ sterile saline containing tubes (Venoject, Terumo- Europe, Leuven, Belgium) separately. All 50 sample containing tubes were vortexed at $2200 \mathrm{rpm}$ for 1 minute to achieve the releasing of bacterial content to the solution. Each tube content were diluated with phosphate buffered saline (PBS) 10 times and 100 times respectively.

$100 \mu \mathrm{l}$ sample was taken by a micropipette and injected into $900 \mu \mathrm{l}$ PBS containing tubes for this process. Afterwards another $100 \mu \mathrm{l}$ sample were taken from this diluated solution to be injected to $900 \mu \mathrm{l}$ PBS containing tubes for 100 times diluation. $100 \mu \mathrm{l}$ sample from this diluations were cultivated in Mitis-Salivarius (Difco laboratories, Detroit, Mich) and 5\% blood agar (Merck AG, Darmstadt, Germany) mediums.

Colonies were visually defined and samples of each colony were studied microscopically after gram staining.
After quantitative assessment of visually and microscopically differentiated groups were subcultured and isolated.

\section{Identification of bacteriae}

Single colony isolated groups were identified by using BBL-Crystal System(BBL Crystal, ANR, GP, Rgp, ID. Becton, Dickinson and Co. Sparks, Shamon, Ireland). Scanning procedure was performed by appropriate software and computer and each of the colonies were identified with $99.8 \%$ accuracy.

Statistical Analysis

Statistical differences were determined by Kruskal-Wallis Analysis of Variance.

\section{RESULTS}

1. Biochemical results

SDS-PAGE analysis

One major Coomasie blue-stained protein band of $\alpha$-amylase with corresponding molecular weight of 34-35 Kd was detected in all samples except feldspathic porcelain (Figure 3). The largest amount of $\alpha$-amylase was determined on Cr-Ni alloy. Amylase deposition was found most for CrNi. Results were confirmed with Bradford Protein Assay (Table 1).

Table 1. Bradford method results of protein amounts

\begin{tabular}{|l|l|}
\hline \multicolumn{1}{|c|}{ Sample } & $\begin{array}{l}\text { Protein amount } \\
(\mu \mathrm{g} / \mathrm{ml} \text { extract })\end{array}$ \\
\hline III (CrNi) & 15.9 \\
IV (titanium) & 9.63 \\
V (AuAgPd) & 7.22 \\
VI (feldspat. Por.) & 4.33 \\
VII (IPS Empress) & 9.5 \\
\hline
\end{tabular}

\section{Microbiological analysis}

Results are shown on Table 2.

Table 2. Mean colonial distribution per material (x105)

\begin{tabular}{|l|l|l|l|l|l|l|l|l|l|l|}
\hline & \multicolumn{2}{l}{ CrNi } & \multicolumn{3}{l}{ AuAgPd } & \multicolumn{2}{l|}{ IPS Empress } & \multicolumn{2}{l|}{ Titanium } & \multicolumn{2}{l|}{$\begin{array}{l}\text { Feldspathic } \\
\text { Porcelain }\end{array}$} \\
\hline & $\mathbf{x}$ & SD & $\mathbf{x}$ & SD & $\mathbf{x}$ & SD & $\mathbf{x}$ & SD & $\mathbf{x}$ & SD \\
\hline S.salivarius & 3,68 & 3,68 & 1,68 & 2,00 & 5,33 & 9,43 & 1,13 & 0,83 & 7,58 & 15,95 \\
\hline S.sanguinis & 11,30 & 18,88 & 0,90 & 1,92 & 4,55 & 5,52 & 12,00 & 8,55 & 19,18 & 43,57 \\
\hline S.vestibul. & 9,03 & 13,36 & 3,38 & 5,15 & 4,18 & 3,54 & 12,00 & 8,55 & 11,62 & 48,23 \\
\hline S.oralis & - & - & 32,90 & 22,00 & - & - & - & - & 8,84 & 20,22 \\
\hline S.parasang. & - & - & 2,75 & 2,87 & 1,80 & 2,92 & - & - & 5,76 & 10,32 \\
\hline L.pseudoms. & - & - & - & - & 0,43 & 0,82 & - & - & 10,00 & 21,79 \\
\hline Staf.epiderm & - & - & 9,35 & 11,51 & - & - & - & - & 10,00 & 43,59 \\
\hline Micrococcus & 0,50 & 1,57 & 0,15 & 0,37 & 0,10 & 0,31 & 0,42 & 0,69 & 0,11 & 0,32 \\
\hline S.sanguis & 6,75 & 11,48 & 1,55 & 2,06 & 13,75 & 18,00 & 2,79 & 2,49 & - & - \\
\hline S.intermedius & - & - & - & - & - & - & 23,32 & 21,77 & 0,05 & 0,23 \\
\hline C.diphteria & - & - & - & - & - & - & 0,35 & 0,49 & - & - \\
\hline Staf.warnerii & - & - & - & - & 0,30 & 0,47 & - & - & - & - \\
\hline
\end{tabular}

\section{Cr-Ni alloy}

S.sanguinis showed significantly higher adhesion comparing other microorganisms. Micrococcus adhesion was found significantly lower than other microorganisms 
$(p<0.001)$. Other bacteriae showed similar adhesion onto Cr-Ni alloy surface.

Au-Ag-Pd alloy

S.oralis was found to adhere most and Micrococcus was found to be least. S.oralis showed significantly higher adhesion. The difference between S.oralis and Staphylococcus epidermidis was insignificant $\left(\mathrm{p}<0.001, \mathrm{X}^{2}=59.026\right)$. IPS Empress

S.sanguis showed the highest adherence and Micrococcus the least. S.sanguis adherence was significantly higher than the other microorganisms $\left(p<0.001, X^{2}=77.137\right)$. Titanium

S.intermedius showed the highest degree of adhesion, followed by S.salivarius, S.sanguinis, Micrococcus, and S.sanguis. C.diphteria revealed the least adhesion $\left(\mathrm{p}<0.001, \mathrm{X}^{2}=69.913\right)$.

Feldspathic porcelain

S.sanguinis adhesion was found to be the most and S.intermedius was the least. S.sanguinis adhered to porcelain surface significantly higher than the other microorganisms found $\left(p<0.001, X^{2}=70.255\right)$.

\section{DISCUSSION}

First stage of bacterial plaque formation on restorative materials is adsorption of acquired pellicle on the material surface. Acquired pellicle is saliva originated and adsorption phenomenon depends on the composition of saliva and surface chemistry of adsorbant material. ${ }^{19}$ The biofilm formed on restorative material is structurally similar to biofilm formed on tooth surface. However, differences in plaque compositions for various restorative materials have not been clearly described. Importance of acquired pellicle is that it allows selective adherence of oral bacteria that are responsible for dental plaque formation. ${ }^{9}$

Initial bacterial adhesion to the acquired pellicle on tooth surfaces are affected from receptor-adhesin interactions based upon stereochemical specifity.9,18 First adherents of acquired pellicle are gram-positive cocci, especially Streptococcus sanguis and Streptococcus mitior. ${ }^{9,11}$ As plaque ages; gram-positive rods begin to dominate the flora. Bacterial population diversifies in 12 hours and Actinomyces, Capnocytophaga, Haemophilia, Prevotella and Veillonella species added to the early colonizers. These so called "late colonizers" are bound to early colonizers by Fusobacterium bridge. ${ }^{9}$

Results of this study are in accordance with previous studies proving the Streptococcal dominance in plaque composition. Also, results of this study demonstrating Staphylococcus epidermidis in plaque composition, are supported by previous literatüre..$^{20-23}$

Steinberg and Eyal ${ }^{23}$ demonstrated S. sobrinus content in the initial bacterial plaque formed on composite and amalgame. Scannapieco et al. ${ }^{22}$ investigated S. sanguis adhesion related to $\alpha$-amylase and showed S.sanguis existence in plaque. Schilling et al. ${ }^{20}$ and Schilling 8 Bowen ${ }^{21}$ reported S.mutans and S.sobrinus adhesion on the glucan coated pellicle in situ. Gabriel et al. ${ }^{24}$ showed Staphylococcus epidermidis adhesion onto Ti alloy surfaces.

In similar in vitro studies, it has been stated that effect of experimental pellicle was different from natural pellicle. ${ }^{16,25-27}$ The lack of enzymatic activity in vitro was found to be the reason for the difference, because this enzymatic activity plays an important role in pellicle adsorption and bacterial adhesion., ${ }^{1,28}$ In this study, the method described by Wise \& Dykema ${ }^{29}$ and Nakazato et al. ${ }^{30}$ was used for pellicle and bacterial plaque formation. But in this study samples were placed on the mandibular denture not palate because saliva pooled in mouth floor contains all secretions from parotid, submandibular and sublingual salivary glands. $3,31,32$

Different methods were introduced for determination of the molecular components of acquired pellicle. These methods are amino acid analysis (random arbitrarily primed PCR, transposane mutagenesis), immunological methods, gel infiltration ion exchange chromatography, histochemical staining, electrophoresis and blast search network. In this study protein content of pellicle was determined by using Laemmli's method33 of sodium dodecyl sulphate polyacrylamide gel electrophoresis (SDS-PAGE) and Bradford Protein Assay. SDS-PAGE was chosen for its accuracy and reliability. ${ }^{34-39}$

The greatest content of saliva is amylase. It was shown that, Streptococci have high affinity to amylase and bind specifically. ${ }^{22,40-42}$ It was found that developed dental plaque includes large quantities of amylase binding streptococci ${ }^{43}$.

The interaction among bacterial adhesion-pellicle-material was investigated repeatedly. ${ }^{13,44-48}$ Besides that many authors have been studying the effect of hydrophobic interactions, zeta potential, porosity on bacterial accumulation for many years. ${ }^{3,49-53}$

Bacterial plaque accumulation was considered from a different point of view in this study. Composition of bacterial plaque formed on various materials was evaluated from chemical and microbiological aspects in details.

The relation between material type and bacterial plaque accumulation was evaluated first by Clayton and Green in 1970. In the study gold, acrylic resin and glazed ceramics were used and insignificant differences in plaque retention amongst the above mentioned materials were found..$^{53}$ Ramberg et al. ${ }^{54}$ evaluated bacterial colonization during de novo plaque formation and actinomyces species were shown to be the most dominant group (\% 50) for day 0 . For the following 4 days none of the actinomyces subgroups 
increased significantly. However, it was found that some streptococci species like capnocytophagae, campylobacteriae, fusobacteriae and A. actinomycetemcomitans sp. increased quantitatively by time.

Wollinsky et al..$^{55}$ found that S.sanguis adhesion to saliva coated titanium is similar to the adhesion onto saliva coated enamel. However, A.viscosus adhesion on titanium surface was less than enamel. According to the results of this study, the adhesion of $A$. viscosus on the titanium surface was found less than the adhesion on the enamel surface, too.

Edgerton et al. ${ }^{56}$ demonstrated increased S.sanguis and S.gordonii challis adhesion on the titanium coated with experimental pellicle. Data obtained from this study proves the bridging role of saliva pellicle components for adhesion of certain streptococcus species. Other researchers showed both of these bacterial species to have specific receptors for salivary amylase and proline-rich proteins. ${ }^{22-35}$ Edgerton et al. ${ }^{57}$ showed proline rich proteins and salivary amylase as precursor components for pellicle on titanium in vitro and those molecules might be responsible for in vivo adhesion of same bacteriae.

In this study $\alpha$-amylase was found on all of the surfaces except feldspathic porcelain. Additionally it was shown that S.sanguis adheres onto all of the surfaces except porcelain. This result gives an idea of a correlation between S.sanguis adhesion and $\alpha$-amylase. More investigations are needed to explain this issue.

\section{CONCLUSIONS}

1.Acquired pellicle content showed similarity for $\mathrm{Cr}-\mathrm{Ni}$, Au-Ag-Pd, Ti alloys and IPS Empress, but SDS-PAGE revealed no $\alpha$-amylase in the biofilm formed on feldspathic porcelain.

2.Composition of initial bacterial plaque showed material specific differences. Nine types of microorganisms were determined on the feldspathic porcelain, five types of microorganisms were determined on $\mathrm{Cr}$-Ni alloy.

Microorganism species determined on the other material surfaces varied between feldspathic porcelain and $\mathrm{Cr}-\mathrm{Ni}$ alloy.

3.Streptococci were determined on all of the materials tested. L. Pseudomesenteroides, Staf. warnei, Staf. epidermidis and Corinobacteria were found to be material specific.

\section{REFERENCES}

1.Baier RE, Glantz PO. Characterization of oral in vivo films formed on different types of solid surfaces. Acta Odontol Scand 1978;36:289-301.

2.Theilade $E$, Theilade T., Role of Plaque in the etiology of peridontal disease and caries. Oral Sci Rev 1976;9:23-63. 3.Waerhaug J. Effect of rough surfaces upon gingival tis- sue. J Dent Res 1956;35:323-325.

4.Waerhaug J. Presence or absence of plaque on subgingival restorations. Scand J Dent Res 1975;83:193-201.

5. Karlsen K. Gingival reactions to dental restorations. Acta Odontol Scand 1970;28:895-904.

6.Sönju T, Rölla G. Chemical analysis of the acquired pellicle formed in two hours on cleaned human teeth in vivo. Caries Res 1973;7:30-38.

7.Steinberg D, Sela MN, Klinger A, Kohavi D. Adhesion of periodontal bacteria to titanium and titanium alloy powders. Clin Oral Implants Res 1998;9:67-72.

8.Siegrist BE, Breckx MC, Gusberti FA, Joss A, Lang NP. In vivo early human dental plaque formation on different supporting substances: A scanning electron microscopic and bacteriological study. Clin Oral Impl Res 1991;2:3846.

9.Kolenbrander PE, London J. Adhere today, here tomorrow: Oral bacterial adherence. J Bacteriol 1993;175:32473252.

10.Jörgensen E. Theilade E, Theilade J, Kelstrup J. Microbiology of denture plaque and its control by chemical agents. Prot Stomat 1980;30:243-248.

11.Berthold $P$. Formation of salivary coating and dental plaque on two different supporting materials, an electron microscopic study. J Periodontol 1979;50:397-405.

12.SönjuT, Glantz PO. Chemical composition of salivary integuments formed in vivo on solids with some established surface characteristics. Arch Oral Biol 1975;20:687691.

13.Gibbons RJ, Hay DI. Adsorbed salivary acidic proline-rich proteins contribute to the adhesion of streptococcus mutans JBP to apatitic surfaces. J Dent Res 1989;68:1303-1307.

14.Gibbons RJ, Hay DI. Human salivary acidic proline rich proteins and statherin promote the attachment of actinomyces viscosus LY7 to apatitic surfaces. Infect Immun 1988;56:439-445.

15.Yao Y, Lamkin MS, Oppenheim FG. Pellicle precursor proteins: acidic proline-rich proteins, statherin and histatins, and their crosslinking reaction by oral transglutaminase. J Dent Res 1999;78:1696-1703.

16.Olsson J, van der Heijde, Holmberg K. Plaque formation in vivo and bacterial attachment in vitro on permanently hydrophobic and hydrophilic surfaces. Caries Res 1992;26:428-433.

17.Adamczyk E, Spiechowicz E. Plaque accumulation on crowns made of various materials. Int $\mathrm{J}$ Prosthodont 1990;3:285-291.

18.Gibbons RJ, Van Houte J. Bacterial adherence and the formation of dental plaques. In Beachey, E.H., ed. Bacterial Adherence. New York: Chapman and Hall Co. 1980 s. 61-104.

19.Kohavi D, Klinger A, Steinberg D, Mann E, Sela MN. 
$\alpha$-amylase and salivary albumin adsorption onto titanium, enamel and dentin: an in vivo study. Biomaterials 1997; 18:903-906.

20.Schilling $\mathrm{KM}$, Blitzer $\mathrm{MH}$, Bowen $\mathrm{WH}$. Adherence of Streptococcus mutans to glucans formed in situ in salivary pellicle. J Dent Res 1989;68:1678-1680.

21.Schilling KM, Bowen $\mathrm{WH}$. Glucans synthesized in situ in experimental salivary pellicle function as spesific binding sites for Streptococcus mutans. Infect Immun 1992;60:284-295.

22.Scannapieco FA, Bergey EJ, Reddy MS, Levine MJ. Characterization of salivary $\alpha$-amylase binding to streptococcus sanguis. Infect Immun 1989;57:2853-2863.

23.Steinberg D, Eyal S. Early formation of Streptococcus sobrinus biofilm on various dental restorative materials. J Dentistry 2002;30:47-51.

24.Gabriel BL, Gold J, Gristina AG, Kasemo B, Lausmaa J, Harrer C, Myrvik QN. Site spesific adhesion of Staphylococcus epidermidis (RP12) in Ti-Al-V metal systems. Biomaterials 1994;15:628-634.

25.Schüpbach $P$, Oppenheim FG, Lendenmann U, Lamkin MS, Yao Y, Guggenheim B. Electron microscopic demonstration of proline-rich proteins, statherin and histatins in acquired enamel pellicles in vitro. Eur $\mathrm{J}$ Oral Sci 2001;109:60-68.

26. Klinger A, Steinberg D, Kohavi D, Sela MN. Mechanism of adsorption of human albumin to titanium in vitro. J Biomed Mater Res 1997;36:387-392.

27. Abbas DK, Albandar JM, Messelt EB, Gjermo P. An in vivo model for the identification of serum proteins in the acquired subgingival pellicle. $\mathrm{J}$ Clin Periodontol 1991;18:341-345.

28. Rykke M, Sönju T. Amino acid composition of acquired enamel pellicle collected in vivo after 2 hours and after 24 hours. Scand J Dent Res 1991;99:463-469.

29.Wise M, Dykema R. The plaque retaining capacity of four dental materials. J Prosthet Dent 1975;33:178-190.

30.Nakazato G, Tsuchiya H, Sato M, Yamauchi M. In Vivo Plaque Formation on Implant Materials Int J Oral Maxillofac Implants 1989;4:321-326.

31.Nyvad B, Kilian M. Microbiology of the early colonization of human enamel and root surfaces in vivo. Scand $J$ Dent Res. 1987;95:369-380.

32.Weerkamp AH, Uyen HM, Busscher HJ. Effect of zeta potential and surface energy on bacterial adhesion to uncoated and saliva-coated human enamel and dentin. J Dent Res 1988;67:1483-1488.

33. Laemmli UK. Cleavage of structural protein during the assembly of the head of the bacteriophage T4. Nature 1970;227:680-685.

34.Absolom DR, Zingg W, Neumann AW. Protein adsorption to polymer particles: role of surface properties. J Biomed Mater Res 1987;21:161-171.
35.Gibbons RJ, Hay DI, Cisar JO, Clark WB. Adsorbed salivary proline-rich protein-I and statherin: receptors for type 1 fimbriae of Actinomyces Viscosus T14V-J1 on apatitic surfaces. Infect Immun 1988;56:2990-2993.

36.Gibbons RJ, Hay DI, Schlesinger DH. Delineation of a segment of adsorbed salivary acidic proline-rich proteins which promotes adhesion of Streptococcus gordonii to apatitic surfaces. Infect Immun 1991;59:2948-2954.

37.Lee JY, Sojar HT, Bedl GS, Genco RJ. Synthetic peptides analogous to the fimbrillin sequence inhibit adherence of P. Gingivalis. Infect Immun 1992;60:1662-1670.

38. Kohavi D, Klinger A, Steinberg D, Sela MN. Adsorption of salivary proteins onto prosthetic titanium components. J Prosthet Dent 1995;7:531-534.

39.Collis JJ, Embery G. Adsorption of glycosaminoglycans to commercially pure titanium. Biomaterials 1992;13:548-552.

40.Douglas CWI. The binding of human salivary $\alpha$-amylase by oral strains of streptococcal bacteria. Arch Oral Biol 1983;28:567-573.

41.Douglas CWI. Characterization of the $\alpha$-amylase receptor of Streptococcus gordonii NCTC 7868. J Dent Res 1990;69:1746-1752.

42.Scannapieco FA, Solomon L, Wadenya RO. Emergence in human dental plaque and host distribution of amylase-binding streptococci. J Dent Res 1994;73:1627-1635.

43.Scannapieco FA, Torres G, Levine MJ. Salivary $\alpha$-amylase: role in dental plaque and caries formation. Crit Rev Oral Biol Med 1993;4:301-307

44.Mayhall CW. Concerning the composition and source of the acquired enamel pellicle of human teeth. Arch Oral Biol 1970;15:1327-1341.

45. Armstrong WG. Origin and nature of the acquired pellicle. Proc Roy Soc Med 1968;61:923-930.

46.Yao Y, Grogan J, Zehnder M, Lendenmann U, Nam B, Wu Z, Costello CE, Oppenheim FG. Compositional analysis of human acquired enamel pellicle by mass spectrometry. Arch Oral Biol 2001;46:293-303.

47.Kraus FW, Mestecky J. Salivary proteins and the development of dental plaque. J Dent Res Special Issue C 1976;55:149-152.

48.Steinberg D, Klinger A, Kohavi D, Sela MN. Adsorption of human salivary proteins to titanium powder. I. Adsorption of human salivary albumin. Biomaterials 1995;16:13391343.

49.Quirynen $\mathrm{M}$, Bollen $\mathrm{CML}$, Papaioannou $\mathrm{W}$, van Eldere J, van Steenberghe D. The influence of titanium abutments surface roughness on plaque accumulation and gingivitis. Int J Oral Maxillofac Implants 1996;11:169-178. 50.Bollen CML, Papaioannou W, van Eldere J, Schepers E, Quirynen M, van Steenberghe D. The influence of abutment surface roughness on plaque accumulation and periimplant mucositis. Clin Oral Implants Res 1996;7:201-211 
51. Kasemo B. Biocompatibility of titanium implants: surface science aspects. J Prosthet Dent 1983;49:832-837.

52.Fujioka-Hirai Y, Akagawa Y, Minagi S, Tsuru H, Miyake Y, Suginaka H. Adherence of S.Mutans to implant materials. J Biomed Mater Res 1987;21:913-916.

53. Clayton J, Green E. Roughness of pontic materials and dental plaque. J Prosthet Dent 1970;23:407-411.

54.Ramberg P, Sekino S, Uzel NG, Socransky S, et al. Bacterial colonization during de novo plaque formation. $\mathrm{J}$ Clin Periodontol 2003;30:990-995.

55.Wolinsky L.E,. de Camargo P.M, Erard J.C., Newman M.G, DDS A Study of In Vitro Attachment of Streptococcus sanguis and Actinomyces viscosus to Saliva-Treated Titanium. Int J Oral Maxillofac Implants 1989;4:27-31.

56. Edgerton M, Lo SE., Scannapieco FA. Experimental Salivary Pellicles Formed on Titanium Surfaces Mediate Adhesion of Streptococci. Int J Oral Maxillofac Implants 1996;11:443-449.

57.Edgerton M, Levine MJ. Characterization of acquired denture pellicle from healthy and stomatitis patients. $J$ Prosthet Dent 1992;68:683-691. 